\title{
PENINGKATAN PEMBELAJARAN PASSING BAWAH DALAM PERMAINAN BOLA VOLI DENGAN METODE BERMAIN MENGGUNAKAN PAPAN PANTUL PADA SISWA KELAS VIII SEKOLAH MENENGAH PERTAMA KRISTEN ABDI WACANA KOTA PONTIANAK
}

\author{
${ }^{1}$ Yaya Sukarya \\ ${ }^{2}$ Fatirul Wa'asil \\ ${ }^{3}$ Samsu Nurfalah
}
Correspondence: Pendidikan Olahraga Pascasarjana Universitas Negeri Jakarta, Jakarta, Indonesia.
E-mail: syaya629@gmail.com

\begin{abstract}
The problem in this research is the ability and skill of passing down technique on the game of volleyball in the students of class VIII Christian High School Abdi Wacana Pontianak is still low. Action Research This class aims to improve lower passing technique skills on volleyball games at grade VIII students Christian Junior High School Abdi Wacana Pontianak through play activities on boards. The subjects of the study were VIII students of the academic year 2014/2015 at Christian Junior High School Abdi Wacana Pontianak, amounting to 24 students. Technique of data collecting by doing direct observation and measurement technique. Data analysis techniques are qualitative and quantitative analysis. The result of the research shows that by using the bounce play method can increase the learning result. The improvement can be seen especially from: a) the learning plan every cycle is very good, b) the implementation of each cycle there is improvement based on the previous reflection, $c$ ) the learning result of the learners increased. Initial data of students who reached KKM 33.33\%, in the first cycle increased to 50\%, and cycle II reached $87.5 \%$.
\end{abstract}

\section{Keywords: Activities, Passing Techniques, Volley Ball}

\section{Pendahuluan}

Pendidikan jasmani pada dasarnya merupakan integral dari sistem pendidikan secara keseluruhan. Bertujuan untuk mengembangkan aspek kesehatan, kebugaran jasmani, keterampilan berpikir kritis, stabilitas emosional, keterampilan sosial, penalaran, tindakan moral melalui aktivitas jasmani.

Proses pembelajaran pendidikan jasmani disekolah tetap menekankan pada proses aktivitas jasmani dengan materi-materi cabang olahraga, salah satunya adalah cabang permainan olahraga bola voli. Menurut Munasifah (2008), menjelaskan bahwa Bola voli adalah permainan yang dilakukan oleh dua regu, yang masing-masing terdiri atas enam orang. Bola dimainkan di udara dengan melewati net, setiap regu hanya bias memainkan bola tiga kali pukulan. Tentunya agar dapat melakukan permainan ini para siswa diwajibkan untuk menguasai teknik dasar permainan diantaranya yaitu servis, passing bawah, passing atas, spike, dan blok. Pada permainan ini hal yang sangat mendasat yaitu penguasaan passing bawah, karena hampir dari semua aspek seperti menerima bola pertama, 
mengumpan, sampai menahan spike lawan sangat memerlukan keterampilan ini. Maka diperlukan metode yang sesuai dengan kebutuhan dan dapat menarik keaktifan siswa dalam belajar.

Guru pendidikan jasmani masih sangat terbatas dalam menggunakan metode bermain sebagai inovasi dalam pembelajaran pendidikan jasmani. Sehingga menjadi malas dalam menuangkan kekreatifan dalam mengajar, padahal dengan metode bermain menggunakan papan pantul sebagai saran pembelajaran yang murah meriah sangatlah membantu guru pendidikan jasmani dalam menyampaikan materi dan siswa juga lebih fokus ketika mengikuti proses belajar karena siswa bisa ikut melihat secara langsung.

Berdasarkan pengalaman dan pengamatan peneliti di Sekolah Menengah Pertama Kristen Abdi Wacana Pontianak hampir keseluruhan siswa bisa melakukan passing bawah tetapi gerakannya masih belum sempurna yaitu gerakan tangan masih tidak lurus sehingga menyebabkan arah bola tidak sesuai dengan yang diinginkan. Pada saat melakukan pengamatan di sekolah tersebut keterampilan siswa dalam melakukan passing bawah masih terbatas.

Hal ini disebabkan beberapa faktor, antara lain pemahaman siswa terhadap permainan bola voli khususnya pada materi passing bawah, siswa kurang bisa memahami teknik dasar dan cara-cara melakukan passing bawah, siswa tidak senang permainan bola voli yang monoton dan membosankan sehingga mempengaruhi hasil belajar siswa kelas VIII Sekolah Menengah Pertama Kristen Abdi Wacana Pontianak. Berdasarkan data yang peneliti peroleh keseluruhan siswa kelas VIII Sekolah Menengah Pertama Kristen Pontianak berjumlah 24 siswa dengan nilai KKM 75. Siswa yang mendapat nilai KKM 75 berjumlah 8 siswa atau 33,3\%, sedangkan yang mendapatkan nilai dibawah nilai KKM 75 berjumlah 16 siswa atau 66,7 \%.

Penelitian tindakan kelas menurut, Jamal Ma'mur Asmani (2011), yang dimaksud dengan PTK ialah sebagai penelitian yang beroentasi pada penerapan tindakan dengan tujuan peningkatan mutu atau pemecahan masalah pada sekelompok subjek yang diteliti. Pemaparan tentang PTK diatas seharusnya mamapu menginpirasi para guru untuk menganalisa segenap proses pembelajaran di kelas yang melibatkan guru dan murid. Hal ini agar metode, kebijakan dan teknik pengajaran bisa benar-benar berjalan secara efektif dan kompetetif. Seorang guru sebaiknya tidak mengganggap bahwa metode yang ia terapkan di kelas sudah cukup dinamis. Diperlukan penelitian untuk bisa menilai dan memastikan hal itu. Dan penelitian tindakan kelas bisa menunjukan manfaatnya. Namun sayangnya, penelitian menjadi barang langka di negeri ini. Mayoritas guru masih asing dengan penelitian sehingga inovasi dan kreasi belum banyak lahir dari ranah pendidikan.

Hal ini harus dicarikan solusi tentunya dengan menggunakan penelitian tindakan kelas dengan pendekatan ini, guru bisa mengintegrasikan ilmu teori ke dalam praktik, baik ilmu tentang bahan yang diajarkan maupun ilmu tentang bagaimana mengajar serta ilmu tentang bagaimana berkomunikasi dengan peserta didik. Menurut, Hamid Darmadi (2011) menyatakan bahwa penelitian tindakan adalah cara suatu kelompok atau seseorang dalam mengorganisasi suatu kondisi 
sehingga mereka dapat mempelajari pengalaman mereka dan membuat pengalaman mereka dapat diakses orang lain.

Menurut, Munasifah (2008), menjelaskan bahwa Bola voli adalah permainan yang dilakukan oleh dua regu, yang masing-masing terdiri atas enam orang. Bola dimainkan di udara dengan melewati net, setiap regu hanya bias memainkan bola tiga kali pukulan.

Sedangkan menurut, Sri Wahyuni dkk (2010) bola voli merupakan salah satu jenis permainan bola besar. Permainan bola voli dilakukan oleh dua regu. Setiap regu terdiri atas enam pemain. Dalam permainan bola voli, setiap regu saling memantulkan bola yang melewati atas net atau jarring. Setiap regu berusaha mematikan gerakan lawan sehingga tidak mampu mengembalikan bola dari pukulan atau pantulan bola dari lawan.

Dari penjelasan diatas dapat disimpulkan bahwa permainan bola voli adalah suatu permainan beregu yang setiap regunya terdiri dari enam orang yang saling memantulkan bola diatas net, dan berusaha untuk mencari poin dengan cara mematikan gerakan atau pukulan lawan sehingga lawan tidak bisa mengembalikan bola ke lapangan regu sendiri.

Dipilihnya metode bermain menggunakan papan pantul sebagai inovasi dalam pembelajaran dengan harapan peserta didik Sekolah Menengah Pertama Kristen Abdi Wacana lebih mudah untuk memahami penjelasan dari guru dan siswa lebih tertarik untuk mempelajari materi Permainan bola voli khususnya passing bawah, sehingga apa yang di pahami oleh peserta didik dapat diingat untuk waktu yang lebih lama, manarik dan menyenangkan.

Menurut, Jahja Yudrik (2011) mengatakan bahwa permainan adalah salah satu bentuk aktivitas social yang dominan pada awal masa anak-anak. Pembelajaran dengan metode bermain adalah pembelajaran dengan cara seolaholah berada dalam suatu situasi untuk memperoleh suatu pemahaman tentang suatu konsep. Dalam metode ini siswa berkesempatanm terlibat secara aktif sehingga akan lebih memahami konsep dan lebih lama mengingat, tetapi memerlukan waktu lama. Fungsi papan pantul disini yaitu sebagai bagian dari permainan yang dapat digunakan sebagai sarana anak dalam bermain.

\section{Metode}

Penelitian adalah cara yang digunakan oleh peneliti dalam mengumpulkan data dari penelitian itu sendiri. Sehubungan dengan masalah yang diteliti. Jenis penelitian yang dilakukan adalah Penelitian Tindakan Kelas (PTK). Arikunto (2010) mengemukakan penelitian Tindakan Kelas merupakan suatu pencermatan terhadap kegiatan belajar berupa sebuah tindakan, yang sengaja dimunculkan dan terjadi dalam sebuah kelas secara bersama. Tindakan diberikan oleh guru atau dengan arahan dari guru yang dilakukan oleh siswa. Penelitian tindakan kelas sebagai berikut: 
Gambar 1. Siklus Penelitian Tindakan Kelas, Suharsimi Arikunto dalam Suyadi (2010)

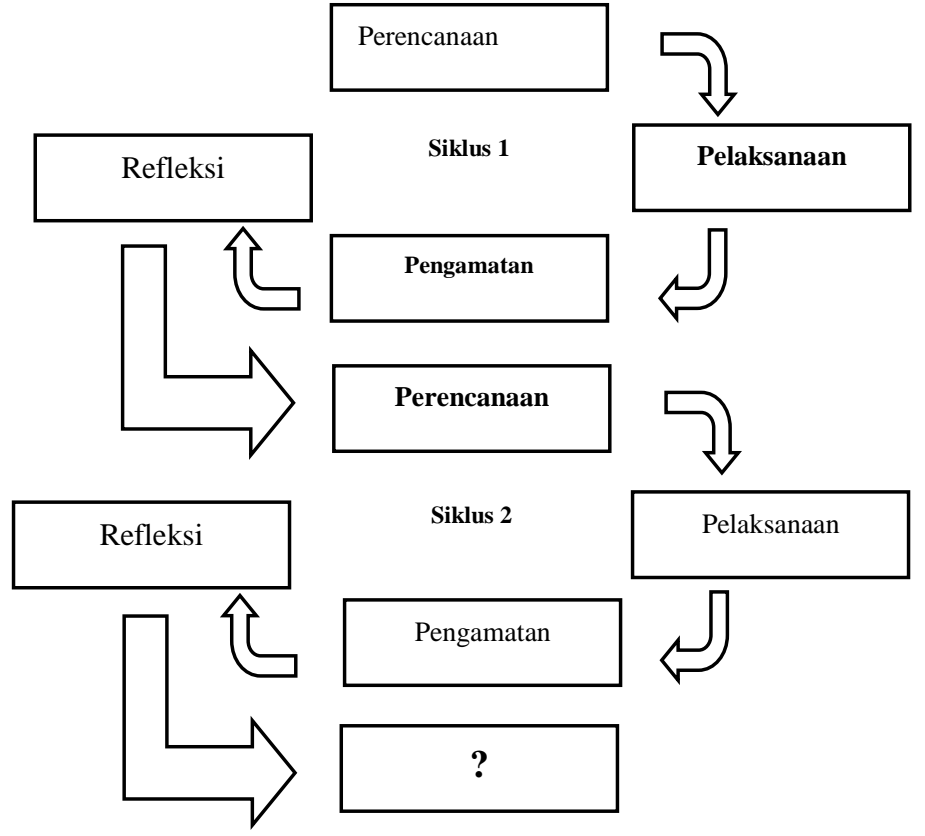

Subyek penelitian pada penelitian ini yaitu siswa kelas VIII tahun ajaran 2014/2015 di Sekolah Menengah Pertama Kristen Abdi Wacana Kota Pontianak yang berjumlah 24 siswa, terdiri dari 13 siswa laki-laki dan 11 siswa perempuan. Obyek penelitian adalah keaktifan siswa proses pembelajaran passing bawah melalui aktivitas bermain papan pantul.

Table 3.1 Distribusi Subjek Penelitian

Jenis Kelamin Subjek Penelitian

\begin{tabular}{lc}
\hline Laki-laki & 13 Siswa \\
\hline Perempuan & 11 Siswa \\
\hline Jumlah & 24 siswa \\
\hline Sumber : TU SMP Kristen Abdi Wacana Pontianak
\end{tabular}

Teknik Pengumpulan Dat, teknik Observasi Langsung yaitu dengan cara mengamati secara langsung keadaan kelas dengan membuat daftar observasi. Menurut, Hadari Nawawi (2006), mengatakan bahwa "teknik observasi langsung adalah cara mengumpulkan data yang dilakukan melalui pengamatan atau pencatatan gejala-gejala yang tampak pada obyek penelitian yang pelaksanaannya langsung pada tempat suatu peristiwa, keadaan, atau situasi sedang terjadi". Teknik observasi langsung adalah cara mendapatkan data yang dilakukan dengan cara pengamatan dan pencatatan gejala yang terjadi pada objek penelitian.

Teknik Pengukuran adalah cara mengumpulkan data yang bersifat kuntitatif untuk mengetahui tingkat atau derajat aspek tertentu dibandingkan dengan norma tingkat tertentu pula. Sebagai ukuran yang relevan. Tes adalah alat atau instrumen yang digunakan untuk mengukur pencapaian tujuan-tujuan 
Teknik Analisis Data adalah serangkaian pengamatan terhadap sesuatu variabel yang diambil dari data ke data dan dicatat menurut urutan terjadinya serta disusun sebagai data statistik. Teknik pengolahan data dalam penelitian ini adalah menggunakan analisis kualitatif dan kuantitatif. Analisis kualitatif digunakan berdasarkan data yang diperoleh dari observasi. Karena data yang diperoleh merupakan data kualitatif, maka analisis data yang dilakukan yaitu menggambarkan atau mendeskripsikan peningkatan pembelajaran passing bawah dalam permainan bola voli dengan metode bermain menggunakan papan pantul.

Sedangkan data yang diperoleh berupa kuantitatif, analisis data yang dipergunakan adalah analisis data kuantitatif melaui tes mengunakan perhitungan statistik dengan mengunakan rumus persentase sebagai berikut:

$$
\text { Nilai }=\frac{\text { skoryang diperoleh }}{\text { skormaksimum }} \times 100
$$

Hasil belajar siswa disesuaikan dengan KKM 75. Kemudian teknik analisis data yang digunakan peneliti untuk menguji kesesuaian tes rata-rata kelas dengan rumus

Keterangan :

$$
N a=\frac{\sum \mathrm{x}}{\mathrm{N}}
$$

$\mathrm{Na}=$ Nilai rata-rata

$\sum \mathrm{x} \quad=$ Jumlah nilai seluruh siswa

$\mathrm{N} \quad=$ Jumlah siswa

Suharsimi Arikunto (2006)

Untuk menghitung persentasi skor ketuntasan belajar digunakan berpedoman pada kriteria ketuntasan menurut, Riduwan (2010) yaitu:

$$
\mathrm{P}=\frac{\sum \text { siswa yang tuntas belajar }}{\sum \text { siswa }} \times 100 \%
$$

Keterangan :

$\mathrm{P}=$ Persentasi

\section{Pembahasan}

Penelitian ini bertujuan untuk mengetahui peningkatan teknik passing bawah pada permainan bola voli pada siswa kelas VIII Sekolah Menengah Pertama Kristen Abdi Wacana Kota Pontianak dengan menggunakan metode bermain. Untuk mencapai tujuan tersebut, dan penelitian tindakan kelas ini peneliti menggunakan metode bermain sebagai perlakuan. Jenis permainan yang dipilih adalah papan pantul. 


\section{Deskripsi Data Hasil Siklus 1}

Perencanaan Perencanaan merupakan program yang berisi tentang kegiatan yang akan dilaksanakan dalam Penelitian Tindakan Kelas. Untuk mendukung pelaksanaan tindakan direncanakan hal-hal sebagai berikut.

1) Refleksi awal, meliputi kegiatan: (1) menyiapkan kegiatan bermain yang harus dilakukan siswa secara berkelompok; (2) menyiapkan cara bermain sebagai stimulus bagi siswa; (3) menyiapkan sarana dan prasarana pendukung; (4) menyiapkan RPP; dan (5) menyiapkan administrasi berupa lembar observasi, dan absen.

2) Menetapkan dan merumuskan rancangan tindakan, pada tahap ini kegiatan yang dilakukan adalah: (1) menentukan tujuan pembelajaran; (2) menyusun kegiatan pembelajaran untuk meningkatkan teknik passing bawah pada permainan bola voli dengan menggunakan metode bermain.

\section{Pelaksanaan}

Pelaksanaan tindakan kelas penelitian ini dilakukan untuk meningkatkan keaktifan dalam bermain pada kelompok. Perlakuan yang diterapkan adalah bermain papan pantul. Pelaksanaan permainan dilakukan dengan tahapan pertama, merencanakan kegiatan meliputi menyusun rencana pembelajaran untuk tindakan, menyiapkan kegiatan pembelajaran, menyiapkan lembar observasi, dan mengkoordinasikan program kerja pelaksanaan tindakan dengan guru lain. Setelah rencana pembelajaran dibuat, selanjutnya dilakukan kegiatan permainan dengan langkah sebagai berikut.

1) Siswa dibagi menjadi 2 kelompok, masing-masing kelompok terdiri 6 orang dengan dipisah oleh net.

2) Ketinggian net seperti net tenis lapangan. Ukuran lapangan menggunakan lapangan bola voli. Masing-masing regu mamainkan bola 4 kali sentuhan.

3) Menggunakan papan pantul, setiap siswa memegang papan pantul masingmasing 1 buah.

4) Cara bermainnya menentukan tim salah satu tim untuk melakukan servis pemain lawan dari tim yang malakukan servis dan bola harus memantul dilantai terlebih dahulu baru dipukul.

5) Cara memukulnya harus sama dengan gerakan tangan pada saat akan melakukan passing bawah. Cara servis satu orang memantulkan bola terlebih dahulu setelah bola memantul keatas pemain yang melakukan servis memukul bola sesuai dengan tata cara memukulnya.

6) Jika melakukan servis maupun melakukan passing bawah yang tidak sesuai dengan tata cara dalam peraturan permainan diatas maka tim tersebut dinyatakan pelanggaran dan poin untul lawan. Dalam game ini tim yang dinyatakan sebagai pemenang tim yang berhasil mencapai angka 15 poin terlebih dahulu

\section{Observasi dan Evaluasi}

Observasi dalam tindakan kelas ini dilakukan pada siswa. Hasil observasi diperoleh melalui pengamatan langsung yang dilakukan peneliti dan dibantu oleh 
observer pendamping/ teman sejawat. Kegiatan yang dilakukan dalam observasi adalah sebagai berikut.

1) Melakukan pengamatan terhadap kegiatan siswa dalam bermain, baik secara individu maupun kelompok

2) Siswa bermain.Menilai keaktifan dan partisipasi siswa secara teliti dan memberikan nilai sesuai dengan hasil yang diperoleh siswa.

Penliaian ini menggunakan lembar observasi langsung. Hasil belajar siklus I dapat pada lampiran nilai post-tes siklus 1. Sesuai dengan Kriteria ketuntasan Minimal yakni 75 dan Indikator kinerja yang ditetapkan pada bab sebelumnya. maka dari tabel hasil refleksi siklus I dapat disimpulkan bahwa jumlah siswa yang mendapat nilai 75 ke atas atau di atas KKM berjumlah 12 siswa dan yang mendapat nilai di bawah KKM berjumlah 12 orang, jumlah siswa keseluruhan 24 siswa. Sedangkan untuk melihat indikator kinerja atau tingkat ketuntasan klasikal siswa dapat dilihat di bawah ini, Jika siswa berhasil mencapai 75\% maka tingkat ketuntasan klasikal tercapai.

Berdasarkan Presentase di atas menujukan rata-rata hasil belajar passing bawah bola voli siklus I tidak tuntas dengan hasil belajar 74,79 sedangkan tes hasil belajar pasing bawah bola voli siklus I siswa yang tuntas ada 12 siswa dengan 50\% dari Kreteria ketuntasan Minimal 75 dan siswa yang tidak tuntas mencapai 12 siswa sebesar 50\% diharapakan dalam siklus ini harus mencapai $75 \%$. Siklus ini belum dinyatakan berhasil karena presentase yang diharapakan masih di bawah tetapi peningkatan dapat dilihat dari kondisi awal dengan yang tuntas hanya 33, 33\% meningkat menjadi $50 \%$. Ketuntasan klasikal hanya mencapai 50\%, maka dapat disimpulkan ketuntasan klasikal atau indikator kinerja tidak tercapai. Sesuai dengan kriteria penilaian SMP Kristen Abdi Wacana maka pada hasil belajar pendidikan jasmani dan kesehatan mendapat kan Nilai $\mathrm{C}$ atau cukup. Karena ketuntasan belum mencapai 75\% ( kriteria ketuntasan klasikal ) maka siklus akan dilanjutkan ke Siklus II. Lebih jelasnya dapat dilihat pada diagram berikut

Gambar 2. Nilai Rata-Rata Jumlah dan persentasi, Siswa tuntas dan tidak tuntas Pada Siklus I

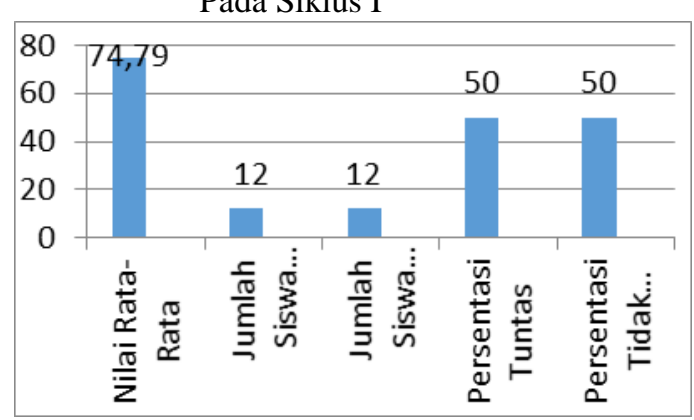


Hasil pada siklus I siswa yang memperoleh nilai di atas 75 sebanyak 12 siswa dengan nilai rata-rata 74,79 dari 24 siswa yang mengikuti post-tes siklus I dengan prosentase $50 \%$ siswa yang Tuntas.

\section{Refleksi}

Berdasarkan pengamatan dan análisis terhadap perencanaan dan pelaksanaan pembelajaran dan hasil observasi dari tindakan siklus pertama dengan dibantu oleh kolaborator. Hasil observasi menunjukkan bahwa indikator penelitian ini belum epenuhnya tercapai, peneliti berupaya menggali faktor penyebab fenomena tersebut, kemudian melakukan refleksi bersma-sama. Setelah melaksanakan dan menyelesaaikan siklus I. Sehingga perlu melakukan refleksi dari pembelajaran yang telah berlangsung diantaranya :

a) Guru mengalami kesulitan dalam penggunaan metode bermain menggunakan papan pantul. Hal ini terlihat pada saat guru memberikan penjelasan siswa kesulitan untuk memahami materi yang disampaikan dan guru masih dalam proses beradaptasi dalam penggunaan metode bermain menggunakan papan pantul.

b) Karena siswa kurang konsentrasi sehingga kerjasama teman satu tim tidak berjalan dengan baik. Hal ini terlihat ketika teman satu tim menerima bola dari lawan masih ada yang diam

c) Siswa kurang menguasai teknik passing bawah.

Berbagai kekurangan yang terjadi pada saat pembelajaran siklus I ini nantinya akan diperbaiki pada saat pembelajaran siklus II agar proses pembelajaran passing bawah bola voli dengan metode bermain menggunakan papan pantul pada siklus II dapat optimal.

\section{Deskripsi Data Hasil Siklus 2}

Perencanaan Perencanaan merupakan program yang berisi tentang kegiatan yang akan dilaksanakan dalam Penelitian Tindakan Kelas. Untuk mendukung pelaksanaan tindakan siklus 2 direncanakan hal-hal sebagai berikut.

1) Refleksi awal, meliputi kegiatan: (1) menyiapkan kegiatan bermain yang harus dilakukan siswa secara berkelompok; (2) menyiapkan cara bermain sebagai stimulus bagi siswa; (3) menyiapkan sarana dan prasarana pendukung; (4) menyiapkan RPP; dan (5) menyiapkan administrasi berupa lembar observasi, dan absen.

2) Menetapkan dan merumuskan rancangan tindakan, pada tahap ini kegiatan yang dilakukan adalah: (1) menentukan tujuan pembelajaran; (2) menyusun kegiatan pembelajaran untuk meningkatkan teknik passing bawah pada permainan bola voli dengan menggunakan metode bermain.

\section{Pelaksanaan}

Pelaksanaan tindakan kelas penelitian ini dilakukan untuk meningkatkan keaktifan dalam bermain pada kelompok. Perlakuan yang diterapkan adalah bermain papan pantul. Pelaksanaan permainan dilakukan dengan tahapan pertama, merencanakan kegiatan meliputi menyusun rencana pembelajaran untuk tindakan,

PJKR_

http://jurnal.unimed.ac.id/2012/index.php/jpehr/index 
menyiapkan kegiatan pembelajaran, menyiapkan lembar observasi, dan mengkoordinasikan program kerja pelaksanaan tindakan dengan guru lain. Setelah rencana pembelajaran dibuat, selanjutnya dilakukan kegiatan permainan dengan langkah sebagai berikut.

1) siswa dibagi menjadi 2 kelompok, masing-masing kelompok terdiri 4 orang dengan dipisah oleh net.

2) Ketinggian net seperti net tenis lapangan. Ukuran lapangan menggunakan lapangan bola voli.

3) masing-masing regu mamainkan bola 6 kali sentuhan. Menggunakan papan pantul, setiap siswa memegang papan pantul masing-masing 1 buah.

4) Cara bermainnya menentukan salah satu tim untuk melakukan servis pemain lawan dari tim yang malakukan servis dan bola harus memantul dilantai terlebih dahulu baru dipukul.

5) Cara memukulnya harus sama dengan gerakan tangan pada saat akan melakukan passing bawah. Cara servis satu orang memantulkan bola terlebih dahulu setelah bola memantul keatas pemain yang melakukan servis memukul bola sesuai dengan tata cara memukulnya.

6) Jika melakukan servis maupun melakukan passing bawah yang tidak sesuai dengan tata cara dalam peraturan permainan diatas maka tim tersebut dinyatakan pelanggaran dan poin untul lawan. Dalam game ini tim yang dinyatakan sebagai pemenang tim yang berhasil mencapai angka 15 poin terlebih dahulu.

7) Setelah Game empat lawan empat selesai dilanjutkan dengan game kedua maka tim di bagi 2 kelompok lagi dan masing-masing kelompok terdiri 3 orang dengan dipisah oleh net.

8) Cara permainannya masih tetap sama yang diganti dalam permainan ini peraturan permainannya yang awal nya 6 kali sentuhan diganti dengan 8 kali sentuhan dan tim yang yang mendapat angka 10 pertama dinyatakan sebagai pemenang.

\section{Observasi dan Evaluasi}

Observasi dalam tindakan kelas ini dilakukan pada siswa. Hasil observasi diperoleh melalui pengamatan langsung yang dilakukan peneliti dan dibantu oleh observer pendamping/ teman sejawat. Kegiatan yang dilakukan dalam observasi adalah sebagai berikut.

1) Melakukan pengamatan terhadap kegiatan siswa dalam bermain, baik secara individu maupun kelompok

2) Siswa bermain. Menilai keaktifan dan partisipasi siswa secara teliti dan memberikan nilai sesuai dengan hasil yang diperoleh siswa.

Penliaian ini menggunakan lembar observasi langsung. Hasil belajar siklus II dapat pada lampiran nilai post-tes siklus II. Sesuai dengan Kriteria ketuntasan Minimal yakni 75 dan Indikator kinerja yang ditetapkan pada bab sebelumnya. maka dari tabel hasil refleksi siklus II dapat disimpulkan bahwa jumlah siswa yang mendapat nilai $75 \mathrm{ke}$ atas atau di atas KKM berjumlah 21 siswa dan yang mendapat nilai di bawah KMM berjumlah 3 siswa, jumlah 
siswa keseluruhan 24 siswa. Sedangkan untuk melihat indikator kinerja atau tingkat ketuntasan klasikal siswa dapat dilihat di bawah ini, Jika siswa berhasil mencapai $75 \%$ maka tingkat ketuntasan klasikal tercapai.

Berdasarkan hasil persentasi ketuntasan kalasikal dalam pembelajaran pasing bawah mencapai 87,5\%, maka dapat disimpulakan ketuntasan kalasikal atau indikator kinerja terlampaui. Sesuai dengan kriteria penilaian SMP Kristen Abdi Wacana Kota Pontianak maka pada hasil belajar penjaskes kelas VIII mendapat kan Nilai A atau sangat baik. Karena ketuntasan melampaui $75 \%$ (kriteria ketuntasan klasikal) maka siklus dihentikan sampai siklus II. Lebih jelasnya dapat dilihat pada diagram berikut.

Gambar 3. Nilai Rata-Rata Jumlah dan persentasi, Siswa tuntas dan tidak tuntas

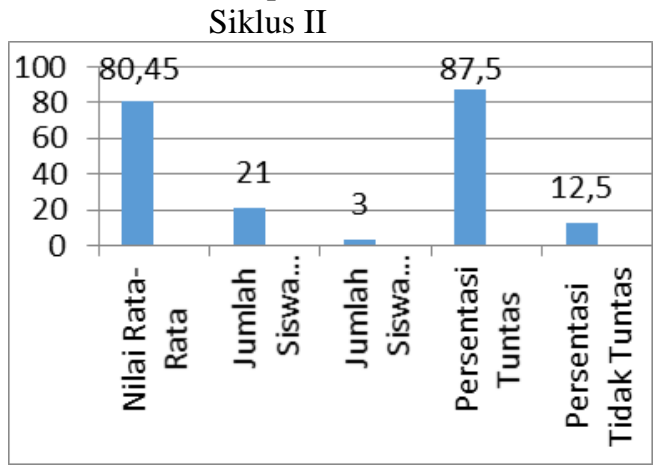

Pada siklus II siswa yang memperoleh nilai di atas 75 sebanyak 21 siswa dengan nilai rata-rata 80,45 dari 24 siswa yang mengikuti post-tes siklus II dengan prosentase ketuntasan mencapai $87,5 \%$ siswa yang tuntas dengan menggunakan metode bermain menggunakan papan pantul dalam pembelajaran telah mengalami peningkatan yang cukup berarti.

Refleksi

Berdasarkan pengamatan dan hasil observasi pada siklus kedua maka dapat diperoleh sebagai berikut:

a) Aktivitas guru dalam melaksanakan pembelajaran

1)Aktivitas guru dalam pelaksanaan proses pembelajaran sudah sesuai dengan rencana pelaksanaan pembelajaran (RPP).

2) Pada kegiatan awal semua kegiatan dilakukan dengan tepat.

3) Tidak ada lagi siswa yang pasif dan mendapat bimbingan.

4) Meningkatnya belajar siswa dengan metode bermain menggunakan papan pantul didukung oleh meningkatnya pengembangan metode guru dalam mengajar secara intensif dan membimbing siswa dan memotivasi siswa selama proses pembelajaran.

b) Aktivitas siswa dalam melaksanakan pembelajaran

Pembelajaran teknik dasar passing bawah bola voli menggunakan pendekatan bermain sudah mampu membangun kerjasama dan rasa tanggung jawab siswa dalam memahami pembelajaran teknik dasar passing bawah bola voli. 


\section{Simpulan}

Berdasarkan hasil penelitian dan pambahasan yang telah dipaparkan dapat disimpulkan bahwa:

1. Perencanaan meningkatkan pembelajaran passing bawah dalam permainan bola voli dengan metode bermain menggunakan papan pantul pada siswa kelas VIII Sekolah Menengah Pertama Kristen Abdi Wacana Kota Pontianak direncanakan melalui mengidentifikasi permasalahan melalui pengambilan nilai tes kemampuan passing bawah. Tahap perencanaan ini telah terlaksana dengan baik, tahap persiapan instrument, penilaian passing bawah dan alat evaluasi pembelajaran telah terlaksana dengan baik sesuai rencana yang ditentukan.

2. Pelaksanaan meningkatkan pembelajaran passing bawah dalam permainan bola voli dengan metode bermain menggunakan papan pantul pada siswa kelas VIII Sekolah Menengah Pertama Kristen Abdi Wacana Kota Pontianak dilaksanakan baik dan benar yang mengacu pada RPP dan Silabus, pada II siklus. Siklus I pelaksanaan kegiatan belajar mengajar passing bawah berlangsung baik dan lancar terlihat dalam hasil pelaksanaan pembelajaran mengalami peningkatan.

3. Observasi meningkatkan pembelajaran passing bawah dalam permainan bola voli dengan metode bermain menggunakan papan pantul pada siswa kelas VIII Sekolah Menengah Pertama Kristen Abdi Wacana Kota Pontianak. Pada siklus I berdasarkan hasil pengamatan proses belajar mengajar pembelajaran passing bawah terlihat adanya perubahan dari sebelumnya, sedangkan pada siklus II berdasarkan hasil pengamatan proses pembelajaran terjadi pada pelaksanaan tindakan kelas berjalan dengan baik dan benar.

4. Refleksi meningkatkan pembelajaran passing bawah dalam permainan bola voli dengan metode bermain menggunakan papan pantul pada siswa kelas VIII Sekolah Menengah Pertama Kristen Abdi Wacana Kota Pontianak. Ditampilkan dalam evaluasi pembelajaran kemampuan passing bawah pada siklus I nilai rata-rata 74,79 dan persentasi ketuntasan klasikal hanya mencapai 50\% masuk dalam predikat "cukup". Sedangkan pada siklus II nilai rata-rata 80,45 dan persentasi ketuntasan klasikal mencapai 87,5\% masuk dalam predikat "baik".

5. Peningkatan meningkatkan pembelajaran passing bawah dalam permainan bola voli dengan metode bermain menggunakan papan pantul pada siswa kelas VIII Sekolah Menengah Pertama Kristen Abdi Wacana Kota Pontianak terbukti berhasil. dapat dilihat dari poin-poin indikator kerja dari data awal, siklus I sampai II yang mengalami peningkatan dari kondisi data awal $33,33 \%$ mengalami peningkatan pada siklus I menjadi $50 \%$ dan mengalami peningkatan lagi pada siklus II menjadi $87,5 \%$.

\section{Rujukan}

Arikunto Suharsimi, 2010. Prosedur Penelitian Edisi Revisi 2010. Jakarta: PT. Rineka Cipta

PJKR_

http://jurnal.unimed.ac.id/2012/index.php/jpehr/index 
Asmani Jamal Ma'mur, 2011. Tips Pintar PTK: Penelitian Tindakan Kelas. Yogjakarta: Laksamana

Darmadi Hamid, 2011. Metode Penelitian Pendidikan. Bandung: Alfabeta Jahja Yudrik, 2011. Psikologi Perkembangan. Jakarta: Prenadamedia Group Nawawi Hadari, 2006. Metode Penelitian Bidang Sosial. Yogyakarta: Gajah Mada University Press

Munasifah, 2008. Bermain Bola Voli. Semarang: Aneka Ilmu 